\title{
Producing and Maintaining Minority "Groupness" through State Effects: Teaching in Croatian in Serbia
}

\author{
Andrew Hodges* \\ Leibniz Institute for East and Southeast European Studies, Regensburg, Germany \\ ${ }^{\star}$ Corresponding author. Email: hodges@ios-regensburg.de
}

\begin{abstract}
This article ethnographically examines the situation surrounding the teaching of Croatian in Serbia. It analyzes the discourses and efforts of minority activists in promoting Croatian culture and language in various ways, specifically drawing on fieldwork conducted in a school where three mutually intelligible language varieties-Serbian, Croatian, and Bunjevac-were taught. Instruction in Croatian has been offered in Serbia since 2002 through a minority rights framework. However, prior to the wars of Yugoslav succession in the 1990s, those identifying as Croat were not considered a minority in [the] Socialist Yugoslavia, as it was a South Slavic federation. The number of children enrolling in Croatian minority programs in Serbia is small, and of those who attend them, a significant number do not come to identify as Croatian, a fact that many minority activists consider to be a problem. The article is organized in four parts. First, the context and various perspectives are introduced through an ethnographic vignette. Second, the research context and legal and institutional framework are introduced. Activist perspectives are then discussed, including tensions present. Finally, Michel-Rolph Trouillot's concept of "state effects" is presented and elaborated with respect to the case study, and the various efforts of activists in trying to promote and/or maintain Croatian "groupness" are evaluated.
\end{abstract}

Keywords: Croatia; Serbia; minority activism; state effects; groupness; Bunjevci; language politics

\section{Introduction: A Parents' Evening}

Toward the end of the 2015 spring term, a parents' evening was organized at the local primary school in the village of Ravnina, ${ }^{1}$ where I was conducting fieldwork. Most of the people living in the village identified as Bunjevci, ${ }^{2}$ an ethnic category closely associated with Catholic belonging and the use of a Bunjevac language variety that was completely mutually intelligible with standard Serbian and Croatian language varieties. Some of the teachers at the school, minority language activists, ${ }^{3}$ and members of the local population understood Bunjevci to be a subgroup of the ethno-national category of "Croats," while others asserted that they were a separate ethnic group, neither Croatian nor Serbian. There was an overlap/ambiguity between the categories of teacher and activist here, given that all the Croatian teachers were committed to promoting Croatian identifications, although in different ways and to varying degrees. The evening was for those parents who had just enrolled their children in the first year of primary school. During the evening, various aspects of school life were showcased, including the Croatian and Serbian language programs in which parents could choose to enroll their children. The event took place in a classroom with a long line of chairs positioned at the front next to the blackboard, where officials associated with the school were asked to sit. These included the headmistress, teachers from the different Serbian and Croatian language programs, as well as the Bunjevac and Hungarian language teachers, teachers from two other locally connected schools, the school 
psychologist, village priest, and myself, who was presented as an anthropological researcher observing the Croatian language classes and as an English teacher helping with a pilot CroatianEnglish bilingual program.

The parents, who had been waiting outside, all came in at once and sat facing us in the chairs where the students would normally sit. The headmistress then spoke, giving a speech in which she emphasized how "we" (both those employed at the school and the parents) are all here to do the same job (literally, task [ mi smo na istoj zadaći]), namely caring for the children and looking after their well-being and development. This framing minimized the distance between those employed at the school and the audience, emphasizing a horizontal solidarity defined through a shared concern for the well-being and development of the children. As she spoke, she emphatically used Bunjevac linguistic identity markers, which indexed local Bunjevac ethnic belonging. These markers consisted of specific vocabulary items (e.g., divaniti [to talk]), certain other lexical features and the use of Ikavian-a language variety that uses an " $\mathrm{i}$ " where there is often an " $\mathrm{e}$ " in standard Serbian, and an "ije/je" in standard Croatian (e.g., mliko/mleko/mlijeko for milk). Given the dominant division present in this context between those who considered Bunjevci to be Croatian and those who considered them to be a separate ethnic group, the headmistress' choice to speak in Bunjevac once again promoted a horizontal solidarity among many people present, eliding divisions between those who identified as Croat and those who did not, as Bunjevac belonging was relatively uncontested.

Following her speech, each of the officials sitting at the front gave a short presentation. The Croatian-English bilingual program that the school was piloting that year was presented first and clearly assumed a central role in the evening's proceedings. I was asked to participate in this presentation. First, the three first-year students enrolled in the program performed a short sketch in English. I then played the game Simon Says ${ }^{3}$ with them in English as we had practiced. Following this, I introduced myself in Croatian, explaining why I was at the school, and commented on how the students had progressed with their English. The Bunjevac teacher, who taught Bunjevac as an optional class while also teaching the Serbian program, then gave a short presentation about the Bunjevac classes. The Bunjevac presentation ended with a short recital of a poem by a student. This teacher had brought two textbooks with her, one in Cyrillic script and the other in Latin script. In Croatia only the Latin script is used at present, while in Serbia both Cyrillic and Latin scripts are used, with Cyrillic favored in state institutions and preferred by the majority of Serbian nationalists. An example sentence emphasizing the differences between the mutually intelligible language varieties, and displaying the different scripts, is listed in Table 1 below. The Bunjevac teacher mentioned that the Cyrillic book came first, as Cyrillic is the first script the children learn in class. In so doing, she implicitly aligned the teaching with the Serbian program as the "normal" option. Any parents interested in Bunjevac classes but planning to enroll their child in the Croatian program would be faced with the added task of teaching their child Cyrillic, as only Latin script was officially used in the Croatian program, and my experience was that no students in the Croatian program attended Bunjevac classes. During their presentations, several of the teachers repeated the headmistress' message of solidarity, using the same phrase, " $m i$

Table 1. Example Sentences.

\begin{tabular}{ll}
\hline English & Не came to Serbia a month ago to speak with adults and children. \\
\hline Bunjevac Íkavian & Došo je u Srbiju pri misec dana, kako bi divanio s odraslima i dicom. \\
\hline Serbian Ekkavian & Došao je u Srbiju pre mesec dana, da bi pričao s odraslima i decom. \\
\hline Serbian Ekavian (Cyrillic) & Дошао је у Србију пре месец дана, да би причао с одраслима и децом. \\
\hline Croatian ljekavian & Dоšаo је u Srbiju prije mjesec dana, kako bi pričao s odraslima i djecom. \\
\hline
\end{tabular}


smo na istoj zadaći." Finally, there was time for questions. The audience of parents appeared shy to speak and so only a few questions were asked, primarily about factual and practical issues such as test results and how to obtain the necessary textbooks, before everybody left.

\section{Researching Croatian Minority Activism in Serbia: Approach and Self-Positioning}

The parent's evening was one event where instruction in Croatian was showcased, with a concerted attempt on the part of the headmistress and other officials to promote it, a process in which I was entangled in promoting the combined Croatian-English teaching. Despite such efforts, only one child enrolled in the Croatian program that year, and the choice to offer a bilingual Croatian-English program (a possibility the Vojvodina regional government had made available on a trial basis) was a further effort on the part of the headmistress to garner interest in the Croatian program, given the practical advantages associated with English language skills in the current labor market. ${ }^{4}$ The low level of interest in teaching in Croatian was not specific to this village, but was present throughout Vojvodina. This situation was viewed as problematic by many Croatian minority activists and academics who were involved in promoting the teaching, although, as we shall later see, the reasons they gave for the lack of interest varied significantly. ${ }^{5}$

This article offers ethnographic material on activist perspectives regarding the teaching as well as the various divisions and positions that emerged. In the second half of the text, methodological insights that may be employed in future ethnographic work with nationally defined minorities are developed. The ethnography is based on one semester (approximately six months) of fieldwork observing a group of third year primary school students enrolled in teaching in Croatian and living in the border village of Ravnina, a mere two kilometers from the SerbianHungarian (and European Union) border. It also draws in places on material from semistructured interviews conducted with the teaching staff and minority officials regarding the Croatian teaching program, Croatian minority language activism, and the situation at the schools where teaching in Croatian was introduced.

I am a UK citizen, who has also lived in Serbia/Croatia for a total of eight years, with complete linguistic immersion during this period, before which I had no knowledge. When commencing fieldwork, I spoke a language variety close to the Croatian standard with certain Kajkavian features ${ }^{6}$ that were commonly used in Zagreb and other locations close to Zagreb. I have a strong practical and theoretical knowledge of Serbian and Croatian language varieties and a particularly strong knowledge of forms associated with standard Croatian. Concerning field access, the fact that I was employed by a Croatian research institute in Zagreb on a grant funded in part by the European Union made access easier and I believe I would have been treated differently had I been employed in Serbia. When conducting fieldwork at the school, I also occasionally taught the students whose classes I attended, as the students and teacher were keen to learn about the UK and the headmistress of the school was keen to put my Croatian and English language skills to use. As my request to conduct fieldwork had overlapped with the introduction of the CroatianEnglish bilingual program in the school, and given my TEFL qualifications and English language teaching experience, I was invited to occasionally teach English classes and help promote the program in a context where extremely few schools in Serbia had "native" English speakers teaching there. A detailed discussion of my teaching engagements and the role I came to assume in the school during fieldwork is beyond the scope of this article.

Theoretically, my approach draws on Rogers Brubaker's (2004) concept of "groupness." As Brubaker $(2004,12)$ described:

Shifting attention from groups to groupness, and treating groupness as variable and contingent rather than fixed and given, allows us to take account of - and, potentially, to account forphases of extraordinary cohesion and moments of intensely felt collective solidarity, without implicitly treating high levels of groupness as constant, enduring, or definitionally present. 
Of particular relevance for this case study is Brubaker's observation that "groupness" may not always happen, despite the efforts of ethno-political activists. Therefore, I understand the production and maintenance of "groupness" (primarily Croatian and/or Bunjevac groupness in this case), as a project undertaken by some individuals at different times, which-as we shall see-is not always successful. Consequently, I do not use the adjective Croatian to reference a preexisting collective entity, but rather use it to refer to political structures connected with the recently formed state named the Republic of Croatia, and to Croatian state effects that attempt to identify subjects and promote Croatian "groupness" for a variety of reasons.

Furthermore, I understand the production and maintenance of national "groupness" to be a phenomenon connected with the rise of modern states. In this vein, Ernest Gellner (2006) famously emphasized the importance of industrialization and mass education, while Benedict Anderson (2006) emphasized secularization and print capitalism, particularly in creating a unified sphere of exchange and communication beneath Latin while being above spoken vernaculars, in generating a new fixity to language, and in consolidating a language of power with attendant hierarchies of linguistic prestige present between language varieties used in everyday settings (Anderson 2006, 46-47). Both of these modernist arguments emphasized the role of education, language standardization, and the dissemination of standardized texts in creating a sense of collective belonging. Such views contrast with those circulating among dominant political elites in Croatia, given the explicit appeal of Franjo Tuđman, the first president of Croatia, to primordialist understandings of national groupness (Đurašković 2015, 2016). My approach has emerged in response to my previous field engagements in Croatia and Serbia during a period of ten years. Relatedly, on a sociolinguistic level, I understand standards such as "standard Croatian" or "standard Serbian" not as a readily identifiable set of linguistic elements, nor as a primordial cultural repository that must be "cared for." Instead, following James Milroy (2001), I understand language standardization as a process into which subjects are enrolled, where norms are promoted and there is an attempt to contruct a standard linguistic register for use in certain contexts, the amount of variation permitted in that register dependent on the attendant language ideologies (Schieffelin, Woolard, and Kroskrity 1998, Silverstein 1979).

This article focuses on the attempted production of Croatian "state effects." Michel-Rolph Trouillot (2001) introduced the concept of state effects as an ethnographic tool designed for the study of the anthropology of the state. Trouillot's state effects include the spatialization, identification, isolation, and legislating of subjects. He argues that modern states exhibit these characteristics, but other institutions, such as nongovernmental organizations or citizen associations, may also exhibit some or all of them. This article, therefore, aims to analyze how, if at all, Croatian minority institutions promote Croatian state effects and whether or not such effects "interpellate" (Althusser 2006) subjectivities or not. School contexts are especially important in this regard, as they are an important ideological site for the production of political (e.g., citizenship and national identifications) and linguistic (e.g., acquisition of standard language ideology) hegemonies (Davis 2012, 61). Before moving to consider how such state effects might have been enacted in the Ravnina context, I first detail the legal and institutional framework and relevant aspects of the context. This includes the impact of minority (language) rights policies and the prospect of Serbia's EU accession. Trouillot's concept of state effects is then applied to the efforts of Croatian minority activists in Serbia, both through linguistic practices in the classroom and through the presence and maintenance of a Croatian minority network. Serbian state effects are also briefly discussed. The paper concludes with a short discussion of the implications of these findings for other contexts.

\section{Teaching in Croatian in Serbia: Context, Policies, and Fieldwork}

The efforts of Croatian minority activists in Serbia were largely focused in and around Subotica, which is located in the northern autonomous region of Vojvodina, the part of Serbia that 
used to belong to the Austro-Hungarian empire. It was considered by many living there to be more European than other parts of Serbia, and it contained a large number of minority identified individuals, often being referred to as a multicultural area with friendly relations among these groups (Archer and Rácz 2012). Vojvodina was an autonomous province for many years and consisted of an area that was formerly part of Austro-Hungary, while certain regions were part of the Axis-controlled Croatian, Hungarian, and Serbian states (UnkovskiKorica 2016) during World War II, and were subject to radical Serbian, Croatian, and Hungarian nationalist claims over large parts of the territory. In this vein, teaching in Croatian was positioned by Bunjevac non-Croatian activists as linking into an expansive project of a greater Croatia:

The aspiration of the Croatian state-national interest towards north-west Bačka refers to the ethnic identity of Bunjevci as a "branch of Croatian clan" supporting this argument with the origins of Bunjevci in Bačka-countries of ancient (mythic) Red Croatia (Herzegovina, Dalmatia). (Raič and Ostojić 2013, 123)

Croatian and Serbian were previously officially considered to be one language, often referred to as Serbo-Croatian before the recent wars, and both Latin and Cyrillic scripts were in use. Following the wars of Yugoslav secession in the 1990s, the Cyrillic script was no longer taught in most schools in Croatia (except in Serbian minority schooling), while as earlier mentioned, it was favored in Serbia. In addition, the Serbian government was funding efforts to standardize the Bunjevac language variety (Ilić and Belić 2014, Belić 2014), which was frequently referred to as a kind of speech (Bunjevački govor). As a language variety, Bunjevac-as earlier mentioned, a form of Ikavian South Slavic - was claimed to be spoken often in the home and informal settings. In addition, the Croatian government offered substantial material support to promote teaching in Croatian in Serbia. These processes occurred alongside recent state-building, specifically a shift from a multi-national state making socialist claims to national (e.g., Serbian and Croatian) states making liberal democratic claims. Political changes, therefore, have included a shift from a primarily solidarity building discourse focusing on "sameness" (encompassing the problematic elision of certain differences) to politics of difference, which has included the "forced recognition" (Spasić in Hodges et al. 2016) of minorities (e.g., sexual and national). Provision for teaching in Croatian became possible following minority rights legislation enacted in 2002, which defined Croats as a national minority in what was then referred to as the rump Yugoslavia, ${ }^{7}$ and what is currently the Republic of Serbia. The Croatian National Council also was formed at that time and teaching in primary schools was introduced during the 2002-2003 academic year and in secondary schools during the 2006-2007 academic year. ${ }^{8}$ Crucially, the ethnic category of "Croats" were considered a "constitutive people" (konstitutivni narod) of the socialist "South Slavic" Yugoslavia, and so those who identified with this category did not have the status of a minority as did, for example, the Hungarian-identified people living in Vojvodina at that time.

Teaching in minority languages in Serbia utilizes a variety of models, referred to as models A, $\mathrm{B}$, and C. ${ }^{9}$ Model A refers to complete teaching in a minority language, with teachers mostly following the Serbian syllabus. Model B refers to bilingual (e.g., Croatian-English teaching), while model C refers to teaching in Serbian alongside an optional minority subject such as "Croatian language with elements of national culture." In Ravnina, models A and B were in use for Croatian, while model $\mathrm{C}$ was used for Bunjevac and Hungarian. Nevertheless, I found that materials using Cyrillic script were used on occasion in the Croatian program, often when the Serbian materials for a particular topic were better quality or more easily available. The situation in Serbia contrasts with states such as Bosnia and Herzegovina, as discussed by Azra Hromadžić (2015). Hromadžić's research was conducted in Mostar, Herzegovina, where students in the different programs followed different "national" syllabuses (Madacki and Karamehić 2012). In Vojvodina, while students followed the Croatian syllabus for the subject of Croatian, as earlier 
mentioned, they followed the Serbian syllabus for almost all other subjects, simply using Serbian materials translated into Croatian in accordance with Serbian law.

The students in the class I worked with came from a variety of backgrounds and engaged with the teaching in different ways. Class sizes in the Croatian program were small, typically consisting of up to five students, with years often combined. In the combined third and fourth year primary level class I observed, there were six students. One came from one of the poorest families in the village, who used to live with ten brothers and sisters by the village rubbish dump in a house with no electricity. In contrast, another student, Ante, regularly visited Croatia and had a holiday home (vikendica) on a Croatian island. Two of the other students, who were sisters, came from Bosnia and Herzegovina. Their mother told me she enrolled them since they spoke Ijekavian in the area of Bosnia where they were from, and so wanted to continue their education in Ijekavian. Another parent told me they enrolled their daughter and son in the Croatian program as it was a more affordable option, and they found it attractive as the class sizes were smaller, so each student would receive more attention. Finally, there was one student in the class who had earlier attended the Serbian program. She had special needs and her mother argued with the Serbian teacher, who had trouble controling her given the class size of thirty and no classroom support workers available to work with Marina. Therefore, her mother decided to put her in the Croatian program since the class size was much smaller. To summarize, the students attending the classes had chosen the program for a wide variety of reasons, ranging from having a greater familiarity with Ijekavian, the advantages of small class sizes, the economic benefits (such as subsidized textbooks and transport), and a desire to preserve Croatian identity and traditions, thus emphasizing the range of symbolic and/or practical considerations that motivated parents to enroll their children into the program.

\section{Promoting Croatian "Groupness": Activist Perspectives}

In April 2014, a year before fieldwork commenced, I made my first contact with Croatian minority activists in Subotica, obtained through students, several of whom were from Subotica, who I had taught in the English department at the University of Novi Sad. The contact they gave me was a man named Hrvoje, who represented a Croatian cultural organization in Subotica. We walked around the town center during which he selected various signs and buildings that were of relevance for the narrative he wished to convey. As we entered the cathedral, Hrvoje, who had also trained as a priest, stated that throughout history only the Catholic Church had taken a just approach to the Croatian language. This comment aligned a specific set of religious institutions with support and advocating for the Croatian language.

We then walked down a road toward the town hall. As we did so, we passed some street art. One piece of graffiti was accompanied by a poem written in Ijekavian, identifiable as Croatian. This writing had been covered with a line, presumably by Serbian nationalists. Hrvoje emphasized that this action was unjust and that texts written in Cyrillic script-currently popularly indexing "Serbianness"-were never marked in Subotica. His comments suggested that some kind of stigma is associated with the use of the Croatian standard in public space in Subotica. The taken-for-granted assumption is that the language varieties indexed "ethnic groups," and that "Croats" as a group (from his perspective) found themselves in an unfavorable position in Serbia. As we shall see, this was a narrative constantly reproduced by this activist, and was then reproduced by members of the Croatian nationalist party (the Croatian Democratic Union [HDZ]) in parliamentary discussions in the Croatian parliament, and was sometimes used as an argument to justify blocking Serbia's EU accession attempts, stating that they needed to improve their treatment of the Croatian minority in Serbia. ${ }^{10}$

We then walked toward the city library where he emphasized that books were available there in Croatian and pointed at a street sign, written in Hungarian, Cyrillic Serbian, and Croatian. Finally, we returned to the office where he worked, where he made two further points. First, he 
emphasized the heterogeneity of local ethnic categories (such as Bunjevci and Šokci), understanding them as part of a larger Croat "family" of ethnic groups, as also stressed by other academic and activist perspectives (Černelić 2005, Žigmanov 2011). Such heterogeneity was understood as a challenge to the promotion of a concrete and more homogenous Croatian group identity, given that the primary identification of many people, in my experience, was with the subgroups. Returning to Brubaker's (2004) concept of "groupness," this activist viewed the lack of Croatian groupness as a problem, and proposed certain interventions (including the promotion of teaching in standard Croatian) as a solution. In the school environment, the promotion of a more homogenous Croatian group identity was attempted by those activists who strongly emphasized standard Croatian in a prescriptivist manner, as discussed elsewhere (Hodges et al. 2016, Vuković 2010). At the metapragmatic level, such promotion frequently involved activists using tropes of "caring for and preserving Croatian identity" in a referential manner, while on a practical day-to-day level, this involved the promotion of cultural activities and teaching in Croatian that could be unambiguously identified as Croatian, such as promoting the use of standard Croatian in the classroom and minority media.

The second point Hrvoje made referred to the unfavorable position of "Croats" in Vojvodina. According to him, "Croats" were victimized in Vojvodina, and many people were afraid to identify as Croatian even though a multicultural narrative persisted in the region (Rácz 2012, Archer and Rácz 2012), as there was in reality a clear hierarchy of minorities regarding access to funding and treatment by Serbian state institutions and "Croats" were near the bottom of this hierarchy, perhaps along with Albanians and Roma. Such a victim narrative played into nationalist definitions of the situation (Jansen 2016, 168; Helms 2013). He also suggested that "Croats" in Vojvodina were near the bottom of a hierarchy of prioritized Croatian minorities as well, with Herzegovinian Croats receiving much more attention.

Hrvoje's views contrasted with those of other activists involved in teaching, including several of the four teachers/coordinators sent to Vojvodina by the Croatian Ministry of Education, and who formed alliances with some of the political opposition to those employed at the Croatian National Council. They insisted on a nonessentialist definition of ethnicity, describing "Croatianness" as a set of narratives that people identify with and advocate for. These activists consistently downplayed any notion of "fear of identifying as Croatian," suggesting this linked into a victim narrative that was politically expedient for the Croatian Democratic Union (HDZ) in Croatia. What was uncontested among all those involved in the minority activist and teaching circuits was the constant indexing of the presence of a Croatian ethnic group in Vojvodina.

One aspect all these activists also had in common was emphasizing the symbolic rather than the communicative aspects of Croatian, given the mutual comprehension between Serbian, Croatian, and Bunjevac language varieties. Croatian linguistic features were often related to a concept of kultura, or a "civilizational sphere," under the jurisdiction of the Roman Catholic Church, with an emphasis placed on the longer literary heritage of the Croatian standard and its relation to education (Peti-Stantić 2008). Nevertheless, being schooled in Serbian was a practical choice for many students ${ }^{11}$ given that it was in general use in state institutions in Serbia where they lived. This was especially the case given that the cost of living in Croatia was much higher than in Serbia, ${ }^{12}$ and so students were more likely to continue their education in Serbia, either in Novi Sad, the capital of Vojvodina, or in Belgrade. Studying in Novi Sad was perceived as a more tolerant option for minority-identified individuals, as Vojvodina included many minorityidentified groupings, and the University of Novi Sad offered courses teaching many minority languages (e.g., Hungarian, Ruthenian, Slovakian), but not Croatian. ${ }^{13}$ For those with limited resources planning to study in Serbia, despite Croatian being mutually intelligible, attending the Serbian program was a more practical choice, as the use of some Croatian forms may be stigmatized in some public contexts (despite having prestige among many in Vojvodina), ${ }^{14}$ while the use of Serbian definitely would not be. For those students simply seeking to learn to read and write and then leave school to work in more practical professions not requiring a detailed 
knowledge of standard forms and formal registers, either of the Croatian or Serbian programs would have been equally practical choices, given complete mutual comprehension between standard language varieties. Given that the teaching offered a number of subsidies from a richer state (e.g., textbooks, transport to a secondary school in the center of Subotica), the Croatian program particularly benefited families struggling with such expenses. The lack of interest in the Croatian program was attributed to a variety of these aspects by different activists: the primary identification with the subgroups, fear of identifying as Croatian, laziness and/or a lack of recognition of kultura, and practical reasons for choosing Serbian and/or majority teaching programs.

Finally, the importance of the close association between religious and national belonging, identifiable in Hrvoje's account of the positive role the Catholic Church had taken toward Croatian, should also be further highlighted. Church officials, such as the (Catholic) village priest in Ravnina, had strong connections with Croatia. Croatian was used frequently in public documents (e.g., song and prayer lists for church services and newsletters) issued by the Catholic Church in Serbia, and when I interviewed him, the village priest stated that the non-Croat identified Bunjevci activists were not as religious or interested in the church as Croatian identified Bunjevci, offering this as an explanation for why materials were not printed in the Bunjevac language variety. When I attended the first communion of the students from the class I attended, all the students during their year at school were involved in the church ceremony. However, students from the Croatian program were almost always chosen to make speeches to the crowd in Croatian, therein emphasizing their privileged position with respect to Catholic Church institutions. When I discussed the Catholic Church's use of standard Croatian with the Bunjevac teacher, she mentioned that Bunjevac activists hoped to have a priest involved and speaking Bunjevac in a local church in the near future.

\section{Tensions}

First, significant tensions existed between Croatian and Bunjevac minority activists. These tensions were manifest in struggles over resources and around the standardization of the Bunjevac language variety. The activist and sociolinguist Petar Vuković $(2014,171)$ claimed that the Bunjevac activists had an overly traditionalist orientation. On his view, standard Croatian (and Serbian) were associated with more modern and urban societies, with Croatian also being viewed by many Croatian language activists as more "cultured" (kulturnije). In this vein, the officials I spoke with at the Croatian National Council and the headmistress of the school emphasized Croatian's status as an official EU language, and the prestige and possible usefulness associated with this status. When visiting the council one day, I asked why students enrolled in Croatian didn't attend the Bunjevac Ikavian classes on occasion, and the answer given was that Bunjevac Ikavian hasn't been standardized and so-from their perspective-it couldn't be taught in schools. Their answer attributed a legitimizing role to the standardization process: standardization legitimates the use of a language variety in state institutions and engenders state recognition (Lane 2011). They viewed the Serbian government's funding for the standardization of Bunjevac Ikavian as an act of Serbian nationalist aggression against the Croatian minority. From a Bunjevac-Croatian culturalist perspective, those involved in the standardization process were perceived as being "on the Serbian side," which is an example of a language ideology in Michael Silverstein's (1979) sense of the term as "sets of beliefs about language articulated by users as a rationalization or justification of perceived language structure and use" (193). Bunjevac primarily connotes authenticity at present, locating language in relationship to a community. As Kathryn A. Woolard (2005) commented, "Within the logic of authenticity, a speech variety must be perceived as deeply rooted in social and geographic territory in order to have value. For many European languages, these roots are in the mountain redoubts of peasant folk purity" (2). In contrast, standard Serbian and Croatian are imbued with the value of anonymity, of a "view from nowhere" (Nagel 1986). However, in Vojvodina, that view from 
nowhere was Serbian, while Croatian-as Marina Balažev (Hodges et al. 2016) noted, was often perceived as foreign.

These tensions were also present among the teaching staff, and the introduction of instruction in Croatian received mixed reactions from the teachers at the school. The Bunjevac teacher at the time was not happy with the decision. One Croatian teacher described how many of the nonCroat Bunjevac teachers in the school (mostly females) had Serbian husbands. Another speculated that the Bunjevac teacher received extra pay (dnevnice) for the Bunjevac classes while they received no extra pay for teaching in Croatian.

Tensions also existed between the leadership working in Croatian minority institutions and those working in the Serbian Ministry of Education, who one year refused to provide funding for the translation of school textbooks into Croatian (while simultaneously providing funding for Bunjevac). This led to a dispute that was covered in the Croatian media as well, as these political distinctions came to a head in the autumn of 2014 when the Serbian government dispensed money for producing textbooks written in Bunjevac (as showcased at the parents' evening). ${ }^{15}$ However, they did not dispense money for translating Serbian curriculum textbooks into Croatian, asserting that the Croatian National Council had missed the deadline for this.

Third, tensions existed among participants in the Croatian minority network, between those who had more political power, and the narratives they conveyed to the ruling HDZ, such as the fear narrative that other activists viewed as damaging. In my personal interactions with teachers and other minority activists, I rarely came across such instances of fear. There was only one occasion where a comment was made by one teacher before the parent's evening, when she stated that it was pointless promoting the Croatian program after enrollment had ended. She didn't want to speak in front of the room of parents when "the village was against us" (selo je protiv nas), a comment that homogenized the variety of perspectives present in the room.

\section{State Effects in the Croatian Minority Context}

What Louis Althusser refers to as the "ideological state apparatus" is useful in understanding how subjects come to align themselves and identify with certain state institutions, or how they are "interpellated"-or not. Academic opinion is divided regarding the extent to which schools played an ideological role in shaping and/or interpellating subjectivities. In the French state context, Pierre Bourdieu (1991) famously argued that "linguistic markets" influence which linguistic features and language varieties are used by particular groups in particular contexts, with reference to existing political-economic relations and "academic capital." Bourdieu argued for communicative competence as contingent on social institutions and relationships established across a "field" strewn with power relations. He attributed a central role to educational institutions in reproducing class hierarchies, and the acquisition and legitimation of standard language as implicated in this process. In contrast, the linguistic anthropologist Woolard (1985) concluded that language varieties and other linguistic features are primarily attributed prestige outside of the classroom, suggesting that the Spanish state's efforts to promote Castilian over Catalan did not succeed, given the relative linguistic prestige attached to Catalan in that context. Woolard's study contests the central role-in some contexts-that Bourdieu attached to educational institutions in reproducing linguistic hegemony. These views might be synthesized in that, if a habitus is predisposed toward a particular outcome before attending school, such a predisposition may leave students open to this being further consolidated in the classroom. Interpellating here, can be considered metaphorically similar to catching or not catching a ballonce it has been caught, it can then be expanded on and grown. However, for those who fail to be interpellated, further efforts to consolidate identifications, in this case Croatian identifications, will likely fail. In other words, once a habitus is configured in a particular way, schools may consolidate that habitus, whereas if it is not, such efforts may not have a significant effect. Higher level effects, including the role pedagogical strategies play when reading literature in inculcating a 
particular kind of critical subjectivity, have also been discussed in Central and Eastern European contexts, including Slovakia (Larson 2009).

Trouillot's concept of state effects-introduced in the next section-allows one to trace certain effects of the ideological state apparatus ethnographically. I discuss two aspects: (1) Croatian state effects as a discursive or linguistic technology enacted through the use of and teaching in standard Croatian that identifies subjects in relation to a Croatian national collective and (2) Croatian state effects associated with the presence and enactment of minority policies and a network for minority activism. Following this, I consider in what ways, if at all, they challenge certain Serbian state effects. Trouillot's "state effects" are listed in Table 2, along with their possible ethnographic effects in this case study, where standard language transmission may be considered as some kind of technology designed to produce state effects.

Before conducting fieldwork, one aim had been to examine, given the context of a mutually intelligible dialect continuum, whether teaching the new Croatian standard could be examined in terms of the attempted transmission of "state effects," through which acquisition of features of standard Croatian promoted an identification with and immersion in hegemonies established by the new Croatian state-that is, that certain Croatian state effects were transmitted in the classroom and in minority activist circles. The field experience showed that such effects were small and that immersion in the Serbian/Croatian state contexts played a far larger role in consolidating an identification with a state.

\section{Spatialization Effect}

Spatial effects associated with minority activism were present in Ravnina, in connection with minority activism. For instance, there was a social space-an ethno-salaš-funded by Milan Bandić, the mayor of Zagreb, in which a Croatian cultural organization had an office. Salaš was a word used in the area for a traditional farmstead, and an ethno-salaš was such a property that had been converted into a venue used to promote cultural tourism. In this case, traditional local

Table 2. Researching State Effects in Minority Activism and Teaching.

\begin{tabular}{|c|c|c|}
\hline State Effect & Definition & Research Questions \\
\hline $\begin{array}{l}\text { Spatialization } \\
\text { effect }\end{array}$ & The production of boundaries and jurisdiction. & $\begin{array}{l}\text { What spatial boundaries emerge in and through } \\
\text { the implementation of Croatian minority } \\
\text { activism and teaching in Croatian? How does } \\
\text { this support and/or subvert spatialization } \\
\text { effects associated with the Serbian state? }\end{array}$ \\
\hline $\begin{array}{l}\text { Legibility } \\
\text { effect }\end{array}$ & $\begin{array}{l}\text { The production of both a language and a } \\
\text { knowledge for governance and of theoretical } \\
\text { and empirical tools that classify and regulate } \\
\text { collectivities. }\end{array}$ & $\begin{array}{l}\text { What tools are used to promote and govern } \\
\text { Croatian minority activism and teaching in } \\
\text { Croatian across different political levels, such } \\
\text { as local government, Serbian, Croatian, and } \\
\text { European political institutions? }\end{array}$ \\
\hline $\begin{array}{c}\text { Isolation } \\
\text { effect }\end{array}$ & $\begin{array}{l}\text { The production of atomized individualized subjects } \\
\text { moulded and modelled for governance as part of } \\
\text { an undifferentiated but specific "public." }\end{array}$ & $\begin{array}{l}\text { How does Croatian minority activism/teaching in } \\
\text { Croatian banally/implicitly and explicitly } \\
\text { construct those involved as members of a } \\
\text { Croatian public? How does the Serbian } \\
\text { syllabus and state effects associated with the } \\
\text { school construct them as members of a } \\
\text { Serbian public? }\end{array}$ \\
\hline $\begin{array}{l}\text { Identification } \\
\text { effect }\end{array}$ & $\begin{array}{l}\text { A realignment of the atomized subjectivities along } \\
\text { collective lines within which individuals } \\
\text { recognize themselves as the same. }\end{array}$ & $\begin{array}{l}\text { How does Croatian minority activism/teaching in } \\
\text { Croatian promote identifications as Croatian, } \\
\text { both linguistically and using other techniques? } \\
\text { How does this contrast with/challenge/relate } \\
\text { to Serbian state identification effects? }\end{array}$ \\
\hline
\end{tabular}


(Bunjevac) meals were served there, along with the performance of local music, dance, and craft activities.

This space was identified with the pro-Croatian activists, while similarly there was another cultural center around which the pro-Bunjevac activists converged. In the school space, as Hromadžić $(2015,433)$ also observed in the case of Mostar, teachers were divided along "ethnic" lines in the staff room, but they all sat at the same table and spoke with one another frequently.

The only student who substantially and consistently identified with Croatia and as a Croat living in Serbia was a student named Ante whose father had specified "preservation of Croatian culture and identity" as the reason for enrolling him, and perhaps more significantly, he was the only student who on a regular basis traversed the state space of Croatia, given that his family had a holiday home on a Croatian island. After crossing the state boundary, spatialized Croatian state effects would enormously increase, therein permitting a stronger identification, visible in and through everything from flags and written signs, to the grounds of uncontested "common sense" assumed in social interactions with others there.

At the end of the fieldwork, the students made a booklet in which they all drew a picture before leaving goodbye messages. Ante's picture was the only one that referenced an experiential dimension connected with a spatialization effect: he had drawn a picture of me in a bus passing a large sign stating, "Welcome to Croatia." A corollary here is that, if the aim of the teaching was to promote identifications such as Croatian, traveling across the space of the Croatian state and being immersed in that state context would likely have a greater effect than any linguistic effect connecting with teaching in standard Croatian-a fact the headmistress of the school in Ravnina implicitly recognized in organizing regular school trips to Croatia for all students at the school who wished/were able to attend, often funded by EU projects that she applied for along with collaborating schools in Croatia.

\section{Legibility Effect}

Trouillot's legibility effect (2001) refers to "the production of both a language and a knowledge for governance and of theoretical and empirical tools that classify and regulate collectivities" (126). This can relate both to the meta-pragmatic level of laws that explicitly prescribe and regulate collectivities, and to the level of concepts enacting such prescriptions. The existence of a framework for "minorities" and a legal articulation defining minority language rights as relating the rights of a group to a nationally defined minority ${ }^{16}$ illustrates this legibility effect, which is assumed by the promoters of the teaching, but not taken for granted by the students and many of the parents. On the part of minority activists, the clearest legibility effect I observed was the promotion of a discourse of caring for and preserving Croatian identity and traditions, which I discuss in detail in another text (Hodges 2017). In a similar manner, as the linguist Kapović (2011) has noted and discussed, precise features of standard Croatian used in textbooks and other written publications and media outlets were highly politicized in Croatia during the 1990s, but to a lesser extent today. Some right-wing authors sought to stress maximum divergence from Serbian, whereas others sought to minimize this difference (while simultaneously accepting many of the prescriptivist interventions). For example, as Mate Kapović (2011) described, "if someone uses the old, pre-1990, orthographical form Evropa (and not the new one, Europa, which is used by the majority in Croatia today), one can safely assume that this person is left-leaning" (51), whereas the extensive use of certain archaisms or prescriptive phrases, including case declensions such as the dative -omu ( $k$ tomu) marks one as right of center. Having lived for several years in Croatia, I was aware of this and instantly noted the differences between standards used in the various textbooks that were used by students in Vojvodina. However, although those who had completed schooling and entered professions such as teaching in Croatia had an awareness of these ideological subtleties, this was not the case in Vojvodina and there was no clear mapping between using specific features of the new Croatian and left/right political views. This suggests 
that immersion in a particular state context and/or experience of particular historical events is key to acquiring certain linguistic hegemonies.

Interestingly, a requirement demanded of me by the Croatian-based ethical committee, who permitted my research to be conducted, was that written communication with Croatian minority institutions (e.g., the Croatian National Council) and the school be conducted in standard Croatian. It is interesting that the requirement itself was framed in terms of use of language, rather than, for example, a framing that emphasized sensitivity regarding the use of language with the various research participants. As a result, individuals (including myself), who had an association with Croatian state institutions, typically communicated using language varieties that primarily indexed the Croatian standard.

\section{Isolation Effect}

The isolation effect (Trouillot 2001) refers to "the production of atomized individualized subjects moulded and modelled for governance as part of an undifferentiated but specific 'public"' (126). One isolation effect was the banal flagging (Billig 1995) of Bunjevci as implicitly and definitively belonging to a "Croatian family of peoples," and of the Croatian state space in Croatian language classes. As almost all subjects followed the Serbian syllabus, the Serbian state space was frequently banally flagged as well, as it was in more general media (e.g., weather reports) available in Vojvodina. In the field context, the failure to inculcate an isolation effect was frequently referred to by minority activists, with reference to the dangers of assimilation. In an interview with an official responsible for education at the Croatian National Council conducted at the end of the fieldwork period as part of the project, she stated, for example, that:

What I have noticed in those classes, in the Croatian programs, is that they more easily express themselves, because they are with their people, among people who think the same. While we have a large number of students from the Croatian national group in the Serbian classes, in those classes they seem to me to be somewhat...off in the corner, as if they can't express themselves well enough. Because our mentality is such that we won't impose ourselves too much, but rather we will withdraw, so as not to make a fuss or raise tensions. ${ }^{17}$

Such dangers were used to argue for the importance of creating a separate Croatian secondary school, designed to be located in the center of Subotica, with instruction being conducted in Croatian. Teachers committed to more multicultural perspectives argued that such a school would have negative consequences on the students:

I am against it. Because children shouldn't be separated... We continually talk about multiculturalism, inter-culturalism - and then we separate them. You have to live together in order to behave like that. But if we separate them in one (Croatian) center, they are on their own. This means that sporting and social activities, whatever, the center will organize by themselves. Why not engage in such activities with Hungarians, Serbs, Slovaks, and Ruthenians and all others, as the schools currently function?

Relatedly, the headmistress mentioned that it had been a mistake not to emphasize a strong connection between teaching in Bunjevac and Croatian when the program was first introduced, as she claimed that there were a number of parents who understood themselves as Croatian but wanted to be taught in Bunjevac Ikavian, since they felt a stronger connection to it than to standard Croatian. A strategy where the Bunjevac language variety would come to be seen as part of a Croatian linguistic and cultural mosaic was preferred by her, but such a focus would not promote a Croatian state "isolation effect" through language. 


\section{Identification Effect}

The identification effect pertains to "a realignment of the atomized subjectivities along collective lines within which individuals recognize themselves as the same." This was evidenced by the Bunjevac teacher's normalization of the Serbian program at the parents' evening, Serbian was the unspoken, "anonymous" default standard, an observation also made by Balažev (Hodges et al. 2016) on the basis of her long-term engagement in teaching Croatian in Vojvodina. Furthermore, a variety of Bunjevac with inflected Serbian Ekavian features that was closer to the Serbian standard was called "prisni bunjevački" (polite Bunjevac). The fact that standard Serbian was consistently the default "view from nowhere" (Nagel 1986) also indicated from a Bourdieusian perspective the presence of an integrated linguistic market, for as Woolard (1985) described, Bourdieu "sees the underpinning of linguistic hegemony as an integrated linguistic market, one integrated under the sponsorship of the state" (740). In Vojvodina the public was surrounded by media, advertising and television mostly, but not exclusively, published in standard Serbian. Croatian television channels are also available and dialectal varieties are used on certain programs.

What, then, might it mean to identify as Croatian in and through activist activities or the promotion of a Croatian language program? As linguistic practices are tightly connected with (cultural) belonging to an imagined collective in this context, I propose considering these dimensions separately in order to denaturalize this distinction. In the school environment, students typically come to identify with a national collective through learning about a history framed in national terms, coupled with the banal reinforcement of such an account outside of the classroom, for instance through print and electronic media. As students followed the Serbian syllabus, they came into contact with a Serbian narrative that was reinforced outside of the classroom. Right-wing Croatian media seized on this, following a visit from the Croatian Ministry of Education (presumably having been informed via connections there), claiming that Croats in Serbia were learning "Greater Serbian" history (i.e., radical Serbian nationalist history). However, identification with a mythico-history-that is, a carefully selected history of events designed to reinforce a moral narrative and identification with a national group (Malkki 1992) - does not only occur through history classes in schools, but also through the subtle reinforcement of particular narratives through day-to-day experience and actions. Such narratives are consolidated through experiences of fear that occur in response to real-time politics and are reinforced by certain kinds of politicians. Although conflicts took place on the territory of Croatia, but not in Vojvodina, there was no historical legacy of fear conducive to groupbuilding as there was in other locations in Croatia, most notably those directly affected by the recent wars.

Standard Croatian was promoted by some activists as a prestige variety, with claims made that it was more cultured - that is, a mark of distinction and legitimacy made with reference to the fact that it was now an official EU language. Such activists in my experience used certain iconic features (e.g., bok [hello], kruh [bread]) that indexed the Croatian standard, and for them, belonging to a Croatian collectivity given the tight relationship between language and culture frequently asserted in this context. Other linguistic features, such as morphology (e.g., organizovati, rather than organizirati [to organize]) were left unchanged. However, the use of Croatian was not generally associated with social prestige outside of activist circles. Other activists, such as the headmistress, as earlier noted, emphatically used Bunjevac linguistic forms often and included them in formal interactions with Croatian officials. This strategically promoted village unity, as Bunjevac belonging was not contested in this context.

\section{Conclusion}

This article has focused on Croatian state effects as experienced in and through the production of a network for Croatian minority activism in Serbia, with an emphasis on teaching practices. 
The ethnographic approach taken has significant limitations, particularly those concerning the generalizability of the insights gleaned from the limited material observed. A key weakness of this study is the lack of perspectives from those not directly involved in the teaching (e.g., parents living in the village) or from those who are indifferent or directly opposed to Croatian minority activism. The students' perspectives are also not considered in this text. Furthermore, the few comments by parents have to be considered in relation to my positioning as connected with Croatian state institutions and coming from Zagreb. Nevertheless, the focus on activists and their efforts accomplished the goal of analyzing how Croatian state effects might have been enacted, or not, in this context. Concerning the language instruction, the material tentatively suggests that traversing the Croatian state space, engaging with mythico-historical narratives, and parental influence/incorporation in the minority activist network were all key in interpellating subjects; and in this context due to the comparative cost of living in Serbia and Croatia, such incorporation thus relates to economic privilege and/or the ability of the school to secure funding for travel to Croatia. Concerning mythico-history, a more balanced approach to history classes would include a discussion of Croatian and Serbian mythico-historical themes alongside one another, but from a critical distance. However, a discussion of detailed policy and/or political implications is beyond the scope of this paper. The modernist approach taken emphasizes how such identifications relate to immersion in a state context that can, under certain conditions, be "misrecognized" as associated with a specific national or minority culture.

More generally, contexts in which linguistic and state hegemonies have been recently consolidated and/or in which they are still contested may offer valuable insights into better understanding how such hegemonies operate and how they shape and are shaped by the everyday concerns of and strategies pursued by people living in such settings. Two added complications in this context relate to recent experiences of war and postsocialist transition that have in turn impacted the meanings attached to three very similar language varieties. The expectation of some Croatian minority activists that many will accept Croatian as the prestige variety likely results from their engagement with Croatian state institutions, engagements that many parents and especially those in rural areas have not experienced. This article sought to tackle minority language activism using tools that are typically used for the study of the anthropology of the state. It would be complemented by an indepth linguistic analysis of register use by activists and in the classroom context, which then could be related to the changing socio-political order. A consideration of interactions with the regional (Vojvodinian government) and Serbian state official perspectives would also be a welcome addition to the analysis offered here.

Acknowledgments. I wish to thank Pedja Kovačević and Tanja Milićev for their extremely useful comments on an earlier version of this paper. I would also like to thank everyone at the school where I conducted fieldwork and the NSLING (University of Novi Sad) and Standardising Minority Languages (University of Oslo) research teams for help and inspiration in developing my ideas, and the three anonymous peer reviewers for their insightful comments.

Financial Support. The research leading to these results received funding from the European Union Seventh Framework Programme (FP7 2007-2013) under grant agreement number 291823 Marie Curie FP7-PEOPLE2011COFUND (The new International Fellowship Mobility Programme for experienced Researchers in Croatia [NEWFELPRO]). This article was written as a part of a project entitled, "Producing and Contesting the National Order of Things: Tracing How Language Standardisation Processes and State Effects Configure (Non)Users Near the Serbian/Croatian Border (BORDERSANTHLING)," which received funding through the NEWFELPRO project under grant agreement number 4.

\section{Notes}

1 I use pseudonyms throughout, and I have changed the name of the village to anonymize it.

2 Bunjevci (plural); Bunjevac, (singular). I retain these spellings throughout. 
3 Simon Says is a game in which participants must follow simple instructions if they are preceded with "Simon Says," and do nothing if they are not. It is particularly effective in teaching new vocabulary and following instructions.

4 For information on the number of students enrolled, see http://hnv.org.rs/docs/NACRT\% 20STRATEGIJE\%20OBRAZOVANJA\%20NA\%20HRVATSKOM\%20JEZIKU\%20U\% 20REPUBLICISRBIJI\%20OD\%202017.\%20DO\%202021..pdf (accessed on May 22, 2017).

5 For an article referencing the lack of interest, see http://www.jutarnji.hr/arhiva/hrvati-uvojvodini-nezainteresirani-za-skole-na-materinjem-jeziku/3786969/ (accessed on January 21, 2017). For an article illustrating the views of some of the more powerful Croatian minority activists' perspectives and issues, see http://www.vecernji.hr/hrvatska/o-domovinskom-ratuuce-da-je-gradanski-zapocet-u-hrvatskoj-1135768 (accessed on January 21, 2017).

6 Kajkavian is a language variety spoken in various parts of North Croatia, especially Zagorje. It used to be spoken in Zagreb, and colloquial language varieties currently spoken in Zagreb have retained certain Kajkavian features, including vocabulary items and grammatical constructions.

7 "Donošenjem Zakona o pravima i slobodama nacionalnih manjina u Skupštini SRJ 26. veljače 2002., hrvatskoj je nacionalnoj zajednici u ovoj zemlji prvi put priznat status manjine.” http:// rs.mvep.hr/hr/bilateralni-odnosi/hrmanjina/ (accessed on May 15, 2017).

8 Ibid.

9 "U Republici Srbiji nastava na hrvatskom jeziku je organizirana u sklopu redovnog obrazovnog sustava u osnovnim i srednjim školama u obliku modela A (kompletna nastava na hrvatskom jeziku prema planu i program Republike Srbije), modela B (dvojezična nastava, hrvatsko-egleski jezik) i modela C (nastava na srpskom jeziku uz izučavanje izbornog predmeta 'Hrvatski jezik sa elementima nacionalne kulture')." http://www.hnv.org.rs/ obrazovanje_na_hrvatskom.php (accessed on March 15, 2017).

10 For example, see http://www.slobodnaevropa.org/a/dvije-manjine-dramaticno-o-svom-polozaju/28133311.html (accessed on January 21, 2017) for a polemical account by a minority representative of the treatment of the Croatian minority in Serbia.

11 I have no data on how language prestige was conveyed in and through Serbian classroom practices.

12 The current average wage in Serbia in 2015 was 361 euros per month, while in Croatia it was 747 euros per month. For a comparison, see http://www.balkaneu.com/serbia-lowest-averagewage-region/ (accessed on January 21, 2017).

13 This was almost certainly due to the political sensitivity resulting from the recent wars and split from Serbo-Croatian. Certain Serbian nationalists did not consider Croatian to be a "language" and open separate studies in Croatian or a department exclusively focused on Croatian literature and language. This would have drawn a significant reaction from the Serbian Right.

14 However, less so than the use of Serbian forms would be in Croatia.

15 See http://www.portalnovosti.com/hocemo-udzbenike-1 (accessed on May 22, 2017).

16 See http://www.ustavni.sud.rs/page/view/sr-Latn-CS/70-100028/ustav-republike-srbije\#d2 (accessed on January 21, 2017).

17 Unless otherwise noted, all translations are my own.

\section{References}

Althusser, Louis. 2006. "Ideology and Ideological State Apparatuses (Notes towards an Investigation)." In The Anthropology of the State: A Reader, edited by Aradhana Sharma and Anil Gupta, 86-111. Malden, MA: John Wiley \& Sons.

Anderson, Benedict. 2006. Imagined Communities: Reflections on the Origin and Spread of Nationalism. London, UK: Verso Archer, Rory, and Krisztina Rácz. 2012. "Šverc and the Šinobus: Small-Scale Smuggling in Vojvodina." In Subverting Borders: Doing Research on Smuggling and Small-Scale Trade, edited by Bettina Bruns and Judith Miggelbank, 59-83. Wiesbaden, Germany: Springer.

Belić, Bojan. 2014. "Bunyev (S): A Linguistic Frontier to Be?" Filoloske Pripombe 12 (1): 603-618.

Billig, Michael. 1995. Banal Nationalism. London, UK: Sage Publications. 
Bourdieu, Pierre. 1991. Language and Symbolic Power. Cambridge, UK: Polity Press.

Brubaker, Rogers. 2004. Ethnicity without Groups. Cambridge, MA: Harvard University Press.

Černelić, Milana. 2005. "Pristupi Istraživanju Bunjevačkih Identiteta.” Studia Ethnologica Croatica 17: $25-49$.

Davis, Christina. 2012. “Is Jaffna Tamil the Best?' Producing 'Legitimate' Language in a Multilingual Sri Lankan School.” Journal of Linguistic Anthropology 22 (2): 61-82.

Đurašković, Stevo. 2015. “Nation-Building in Franjo Tuđman’s Political Writings.” Politička Misao 51 (5): 58-79.

Đurašković, Stevo. 2016. "National Identity-Building and the 'Ustaša-Nostalgia' in Croatia: The Past That Will Not Pass." Nationalities Papers 44 (5): 772-788.

Gellner, Ernest. 2006. Nations and Nationalism. Ithaca, NY: Cornell University Press.

Helms, Elissa. 2013. Innocence and Victimhood: Gender, Nation, and Women's Activism in Postwar Bosnia-Herzegovina. Madison, WI: University of Wisconsin Press.

Hodges, Andrew, Amelia Abercrombie, Marina Balažev, James Costa, Mate Kapović, Jelena Marković, Tanja Petrović, and Ivana Spasić. 2016. "Croatian Language Standardization and the Production of Nationalized Political Subjects through Language? Perspectives from the Social Sciences and Humanities.” Etnološka Tribina: Godišnjak Hrvatskog Etnološkog Društva 46 (39): 3-45.

Hodges, Andrew. 2017. “The Importance of Being Patriotic: Enregistered Connections in Croatian Minority Activism.” East European Politics and Societies 31 (3): 615-636.

Hromadžić, Azra. 2015. "Dissatisfied Citizens: Ethnonational Governance, Teachers' Strike and Professional Solidarity in Mostar, Bosnia-Herzegovina." European Politics and Society 16 (3): 429-446.

Ilić, Marija, and Bojan Belić. 2014. "Eine neue Sprache entsteht, die bunjewakische 'Sprache' oder 'Sprachmund' in der Grundschule." In Südosteuropa Jahrbuch, Band 40, edited by Christian Voß and Wolfgang Dahmen, 93-114, Munich: Verlag Otto Sagner.

Jansen, Stef. 2016. "First as Tragedy, Then as Teleology: The Politics/People Dichotomy in the Ethnography of Post-Yugoslav Nationalization." Conflict and Society 2 (1): 164-180.

Kapović, Mate. 2011. "Language, Ideology and Politics in Croatia." Slavia Centralis IV/2, 45-56.

Lane, Pia. 2011. "The Birth of the Kven Language in Norway: Emancipation through State Recognition." International Journal of the Sociology of Language 209: 57-74.

Larson, Jonathan. 2009. "Cosmologies of Criticism: Taste, (Dis) Trust, and Uses of Literature in Slovak Secondary Schools." Critique of Anthropology 29 (4): 447-469.

Madacki, Saša, and Mia Karamehić. 2012. Dvije Škole Pod Istim Krovom: Studija O Segregaciji U Obrazovanju. Sarajevo, Bosnia and Herzegovina: Centar za ljudska prava Univerziteta u Sarajevu Asocijacija Alumni Centra za interdisciplinarne postdiplomske studije (ACIPS).

Malkki, Liisa. 1992. "National Geographic: The Rooting of Peoples and the Territorialization of National Identity among Scholars and Refugees." Cultural Anthropology 7 (1): 24-44.

Milroy, James. 2001. "Language Ideologies and the Consequences of Standardization.” Journal of Sociolinguistics 5 (4): $530-555$.

Nagel, Thomas. 1986. The View from Nowhere. Oxford, UK: Oxford University Press.

Peti-Stantić, Anita. 2008. "Jezik naš i/ili njihov." Vježbe Iz poredbene povijesti južnoslavenskih standardizacijskih procesa. Zagreb, Croatia: Srednja Europa.

Rácz, Krisztina. 2012. "By the Rivers of Babylon: Multiculturalism in Vivo in Vojvodina/Vajdaság.” Jezikoslovlje XIII (2): 585-599.

Raič, Aleksandar, and Suzana Ostojić. 2013. "Bunjevci and Croats in Serbia: Problem of Democratic Solution of an Ignored Ethnic Conflict." In National Question in Central Europe: Democratic Responses to Unresolved National and Ethnic Conflicts, edited by András Lörincz, 121-134. Budapest: Institute for Cultural Relations Policy.

Schieffelin, Bambi B., Kathryn A. Woolard, and Paul V. Kroskrity. 1998. Language Ideologies: Practice and Theory. New York: Oxford University Press.

Silverstein, Michael. 1979. "Language Structure and Linguistic Ideology." In The Elements: A Parasession on Linguistic Units and Levels, edited by Paul Clyne, William Hanks, and Carol Hofbauer, 193-247, Chicago, IL: Chicago Linguistic Society.

Trouillot, Michel-Rolph. 2001. "The Anthropology of the State in the Age of Globalization: Close Encounters of the Deceptive Kind." Current Anthropology 42 (1): 125-138.

Unkovski-Korica, Vladimir. 2016. "World War II and the National Question: The Origins of the Autonomous Status of Vojvodina in Yugoslavia.” Europe-Asia Studies 68 (10): 1712-1735.

Vuković, Petar. 2010. “Kako Skrbiti Za Hrvatski Jezik U Vojvodini?” In Godišnjak Za Znanstvena Istraživanja ZKVH-A, edited by Tomislav Žigmanov, 79-103. Subotica, Serbia: Zavod za kulturu vojvođanskih Hrvat.

Vuković, Petar. 2014. "Jezični Program Bačkih Bunjevaca Nehrvata." In Bunjevci u Vremenskom i Prostornom Kontekstu, edited by Jadranska Černelić and Milena Černelić, 161-176. Zagreb: FF press. 
Woolard, Kathryn A. 1985. "Language Variation and Cultural Hegemony: Toward an Integration of Sociolinguistic and Social Theory." American Ethnologist 12 (4): 738-748.

Woolard, Kathryn A. 2005. "Language and Identity Choice in Catalonia: The Interplay of Contrasting Ideologies of Linguistic Authority.” University of California San Diego Linguistic Anthropology Working Papers.

Žigmanov, Tomislav. 2011. “Osvajanje Slobode: Hrvati U Vojvodini Deset Godina Nakon Listopadskog Prevrata 2000.” Subotica, Serbia: Hrvatsko Akademsko Društvo.

Cite this article: Hodges, A. 2018. Producing and Maintaining Minority "Groupness" through State Effects: Teaching in Croatian in Serbia. Nationalities Papers 47: 55-71, doi:10.1017/nps.2018.12 